\title{
Feeding of Oncaea curvata (Poecilostomatoida, Copepoda)
}

\author{
C. Metz* \\ Alfred-Wegener-Institut für Polar- und Meeresforschung, Columbusstraße, D-28560 Bremerhaven, Germany
}

\begin{abstract}
Oncaea curvata is one of the dominating copepod species of the Antarctic in terms of numbers, and in the vicinity of the shelf often also in terms of biomass. However, little is known about its role in the ecosystem. The experiments of this study show that $O$. curvata females prefer large, nonmotile food particles such as aggregates or gelatinous Phaeocystis colonies. Up to $18 \%$ of their body carbon was ingested daily from a Phaeocystis cf. pouchetii culture at natural concentrations, and up to $35 \%$ from a Phaeocystis bloom, which consisted of gelatinous colonies with other flagellate species and diatoms. The highest ingestion rates of about $300 \%$ of their body carbon per day were measured when feeding on a Phaeocystis bloom at higher than ambient concentrations. Diatoms were an acceptable food as well. The daily carbon uptake amounted to $2-26 \%$ of $O$. curvata's body carbon at natural chlorophyll a concentrations. Accordingly this species may have as much influence on phytoplankton stocks as calanoid copepods. In contrast to many other Oncaeidae, $O$. curvata females were not carnivorous and did not feed on motile food (copepods or flagellates).
\end{abstract}

KEY WORDS: Copepod - Oncaea curvata feeding $\cdot$ Antarctic

\section{INTRODUCTION}

Copepods of the genus Oncaea (Poecilostomatoida, Copepoda) occur worldwide in high abundances. They inhabit different habitats from the tropics to the polar regions and from shallow areas to the deep sea (e.g. Turner \& Dagg 1983, Nishida 1985, Schnack et al. 1985, Böttger-Schnack 1990, Paffenhöfer 1993) and often dominate numerically. However, they have been grossly neglected in former investigations of plankton. There are few studies of the Oncaeidae, and they are often only mentioned together with Oithonidae as 'cyclopoid copepods'. This is partly due to the sampling, which has mainly been in the upper part of the water column, where other species are abundant as well, and partly due to the small size of these copepods. It is their small size and their high abundance that probably allocates them an important role in the food web of pelagic communities. The Oncaeidae are ideal food organisms for fish larvae (Kellerman 1987) and other planktonic predators such as the calanoid

\footnotetext{
- Present address: University of Wales, Bangor, E \& IP Unit, Gwynedd LL572DG. UK.E-mail c.metz@bangor.ac.uk
}

copepod Euchaeta sp. (Øresland \& Ward 1993) and chaetognaths ( $\varnothing$ resland 1990). Small facultatively carnivorous or omnivorous organisms also use Oncaeidae as food (Metz \& Schnack-Schiel 1995). Only a few investigations into the feeding habits of the genus Oncaea have been made. Hopkins \& Torres (1988) found remains of diatoms in their guts and Turner (1986) concluded that Oncaea were omnivorous because of their fecal pellet contents. Wickstead (1962) suggested a raptorial feeding habit for Oncaea, either as predator or semiparasitic/ectoparasitic on larger zooplankton. Only Paffenhöfer (1993) has worked experimentally with Oncaea. His data suggest omnivorous feeding.

In Antarctic waters there are several species of Oncaeidae, but the dominant species is the endemic, epipelagic Oncaea curvata. This species is very abundant and often dominates in terms of numbers or even in terms of biomass, especially in the shelf region (Metz 1996). However, its role in the pelagic food web of that area is unknown. Therefore, the purpose of this study was to investigate the feeding habits of $O$. curvata, especially food preferences and the effect of different conditions on feeding rates. 


\section{MATERIAL AND METHODS}

During 2 expeditions with the RV 'Polarstern' to the southern Bellingshausen Sea, west of the Antarctic Peninsula (Fig. 1), in January to March 1994 and in April 1995, live animals for experiments were caught from the upper $500 \mathrm{~m}$ of the water column with a Bongo net. It had a mesh size of $100 \mu \mathrm{m}$ and an opening of $60 \mathrm{~cm}$ diameter. Oncaea curvata females were sorted from the catch under a Wild M3 dissecting microscope as soon as possible, and transferred to $2 \mathrm{l}$ jars with filtered seawater and algae from different cultures. The jars were sealed without air bubbles and rotated on a Ferris wheel at $0.5 \mathrm{rpm}$ at $0^{\circ} \mathrm{C}$ and in dimmed light for at least $3 \mathrm{~d}$ to adjust the copepods to laboratory conditions before setting up the experiments. The slow rotation simulates microturbulence and prevents algae and copepods from sinking to the bottom of the jars. During the acclimation period the $O$. curvata females were fed with the respective food organisms of the following experiments

During the first expedition, experiments to quantify herbivorous feeding were conducted with cultures of the diatom Porosira pseudodenticulata [culture from M. Baumann, Alfred-Wegener-Institut für Polar- und Meeresforschung (AWI), Bermerhaven, Germany], which occurrs mainly as single cells or 2-cell chains, and the flagellate Prorocentrum redfieldii (culture from M. Elbrächter, Biologische Anstalt Helgoland, Germany). In addition, 2 mixed cultures were grown

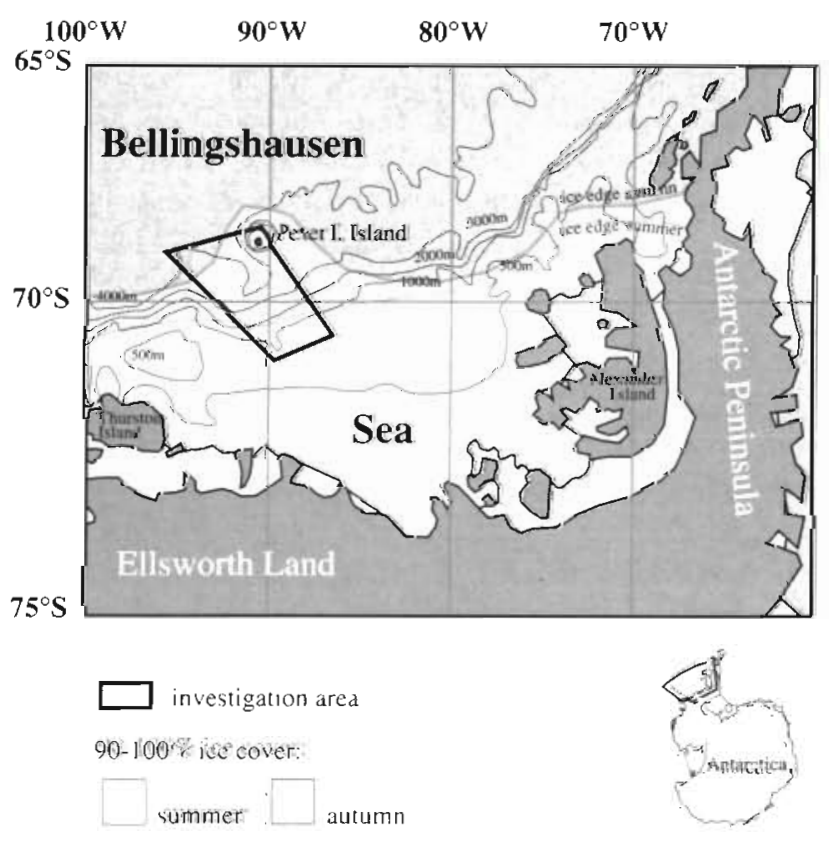

Fig. 1. Investigation area, southern Bellingshausen Sea from in situ water samples for other experiments. The culture 'ice algae' was dominated by different pennate diatoms from the ice, and the culture 'Phaeocystis bloom' by gelatinous colonies of Phaeocystis sp. The latter culture contained large diatom species as well. During the second expedition in autumn cultures of Phaeocystis of. pouchetii (from L. Medlin, AWI) were tested as food. The algae were reared in the lab at $0^{\circ} \mathrm{C}$ (for $P$. pseudodenticulata, 'ice algae', 'Phaeocystis bloom' and $P$. cf. pouchetii) or in an incubation refrigerator at $5^{\circ} \mathrm{C}$ (for $P$. redfieldii). At constant light they were cultivated to high densities in Drebes medium (for diatoms) or $\mathrm{f} / 2$ medium (for flagellates). To keep the algae growing, the cultures were diluted with new medium every 3 to $7 \mathrm{~d}$.

For the feeding experiments with Oncaea curvata, 0.51 jars were filled with algae suspension, 5 to 80 copepods were added, depending on the algae concentration, and the jars were sealed bubble free. These jars were incubated on the Ferris wheel under laboratory conditions for $24 \mathrm{~h}$, thus avoiding effects of diurnal changes in feeding rates on the experiments. At the beginning and end of every experiment water samples were filtered onto GF/C filters, and chlorophyll a (chl a) was measured with a Turner fluorometer (Evans \& O'Reilly 1983). During the first expedition the measurements were done immediately after the experiment on board ship. The samples from the second cruise were frozen at $-20^{\circ} \mathrm{C}$ and measured 2 mo later, in the lab. The chl a concentrations in the experiments ranged between 0.1 and $25 \mu \mathrm{gl}^{-1}$, to cover the range of concentrations occurring in different habitats of Antarctica.

Carnivorous feeding of Oncaea curvata was tested with calanoid copepods during the summer expedition. Nauplii, copepodids and adults of Calanus propinquus, Calanoides acutus, Rhincalanus gigas and Metridia gerlachei were isolated from Bongo net hauls and reared in beakers with algae suspensions at $0^{\circ} \mathrm{C}$. For the experiments $O$. curvata females were transferred into $200 \mathrm{ml}$ dishes, which contained a known number of calanoid nauplii, juveniles or adults of the above mentioned species in filtered seawater (see Table 2). The number of animals at the beginning and end of the 24 hour experiments was recorded and the behaviour of the animals observed. During experiments with copepodids and adults the containers were also checked every $3 \mathrm{~h}$ and the animals counted. During the sorting of the hauls the behaviour of $O$. curvata relative to other animals was observed.

Mean food concentrations in the experiments, volume swept clear (VSC) and ingestion rates (I) were calculated according to the equations of Frost (1972). The ingestion rates are given in $\mu \mathrm{g} C$ female $\mathrm{e}^{-1}$. To convert chl a values to carbon, a factor of 40 was used 
(Lenz 1974). VSC and $I$ were plotted against the mean food concentration in the experimental jars. For $(0.5 \mu \mathrm{g}$ chl a $1^{-1}$ )-classes mean VSC and $I$ and their 'mean absolute deviation from the mean' (MA) was calculated according to the following equation:

$$
\mathrm{MA}=\sum\left|x_{1}-\bar{x}\right| \mathrm{n}^{-1}
$$

where $x_{i}$ represents the datapoints, $\bar{x}$ the mean and $n$ the number of datapoints. The daily carbon uptake as a percentage of the body carbon of the females was calculated from the ingestion rates and the measured mean carbon content of the females.

During the autumn expedition 16 samples of Oncaea curvata females and 5 samples of $O$. curvata males were obtained for carbon analysis from Bongo net hauls at Stn 69 (8 April 1995) at $63^{\circ} 26.7^{\prime} \mathrm{S}$, south of the Polar Front, and Stn 104 (12 April 1995) at $69^{\circ} 24.6^{\prime} \mathrm{S}$. From the hauls, 7 to $10 \mathrm{O}$. curvata per sample were sorted, cleaned overnight in filtered seawater and then transferred to small silver capsules with fine forceps. These samples were frozen on board at $-80^{\circ} \mathrm{C}$. The carbon content was measured using the EasyQuant Carbon Analyzer EQ 92 of H.-J. Hirche (AWI). This instrument burns the carbon in the sample and measures the resulting $\mathrm{CO}_{2}$ in a cuvette with a very sensitive double-beam infrared photometer. The carbon analyzer was calibrated with oxalic acid standards. The results (see Table 1) were converted into carbon content per individual (body carbon). The copepods for the feeding experiments originated from the area of Stn 104. Therefore, for the calculation of the feeding rates, only values from Stn 104 were used, because of extreme regional differences in the carbon content of this species. These were statistically proved by application of a $t$-test to the results of the carbon analysis.

\section{RESULTS}

\section{Carbon measurements}

The carbon contents of Oncaea curvata adults showed little variability within stations but were significantly different between stations (Table 1). According to statistical tests, the mean carbon contents of $O$. curvata females at Stn 69 are significantly ( $p>99.9 \%$ ) lower than at $\operatorname{Stn} 104$. The difference is not as pronounced in the males $(95 \%<\mathrm{p}<99 \%)$. Stn 69 was far north of the investigation area, but south of the Polar Front, in an area with extremely low chl a concentrations in the water column $\left(<0.01 \mu \mathrm{g} \mathrm{chl} \mathrm{a} \mathrm{^{-1 }}\right)$. At the more southerly Stn 104, in the investigation area, the chl a content in the upper $50 \mathrm{~m}$ reached a maximum of $0.23 \mu \mathrm{g} \mathrm{chl} \mathrm{a} \mathrm{l}^{-1}$.
Table 1. Oncaea curvata. Carbon content ( $\mu \mathrm{g} \mathrm{C}$ ind.$^{-1}$ ) with mean $(x)$ and standard deviation (SD) of females and males (in parentheses: number of individuals per measured sample)

\begin{tabular}{|lcccc|}
\hline & \multicolumn{2}{c}{ Station 69} & \multicolumn{2}{c|}{ Station 104} \\
& Female & Male & Female & Male \\
\hline & $0.73(10)$ & $0.57(20)$ & $1.67(10)$ & $0.69(20)$ \\
& $0.96(10)$ & $0.51(7)$ & $1.53(12)$ & $0.74(20)$ \\
& $0.72(10)$ & & $1.40(10)$ & $0.70(20)$ \\
& $0.89(10)$ & & $1.66(10)$ & \\
& $0.61(10)$ & & $1.70(10)$ & \\
& $0.45(20)$ & & $1.48(10)$ & \\
& $0.76(20)$ & & $1.45(10)$ & \\
& $0.65(9)$ & & $1.49(10)$ & \\
$\bar{x}$ & $0.72(99)$ & $0.54(27)$ & $1.55(82)$ & $0.71(60)$ \\
SD & 0.16 & 0.04 & 0.12 & 0.03 \\
& & & & \\
\hline
\end{tabular}

\section{Herbivorous feeding}

The diatom Porosira pseudodenticulata occurred normally as single cells of an average diameter of $18.5 \mu \mathrm{m}$ or as short 2 -cell chains. When Oncaea curvata females fed on this diatom, the clearance rate (VSC) decreased with increasing food concentration. The highest VSC measured was $33.4 \mathrm{ml}$ female $\mathrm{e}^{-1} \mathrm{~d}^{-1}$ (Fig 2a). The ingestion rates (Table 2) increased with increasing food concentration up to $6.9 \mu \mathrm{g} \mathrm{chl} \mathrm{a} \mathrm{l}^{-1}$ (Fig. 2a). With higher chl a concentrations, I decreased again.

Using the culture of 'ice algae', which consisted mainly of pennate diatoms from the ice (Fragillaria sp. and others) as food, the mean VSC decreased more strongly with increasing food concentration (Fig. 2b) than with the monoculture described above. Especially

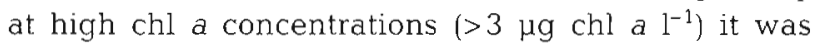
clearly lower in this series of experiments. Exceptions are the 2 relatively high VSC of 3.3 and $1.7 \mathrm{ml} \mathrm{female}^{-1}$ $\mathrm{d}^{-1}$ at 12 and $16 \mu \mathrm{g} \mathrm{chl} \mathrm{a} \mathrm{l}^{-1}$. In these 2 experiments with high algae concentrations the algae began to clump, so

Table 2. Oncaea curvata. Herbivorous feeding on Porosira pseudodenticulata, ice algae, Phaeocystis cf. pouchetii, or a Phaeocystis bloom. Highest mean values of ingestion rates ( $\mu \mathrm{g} \mathrm{C}$ female ${ }^{-1} \mathrm{~d}^{-1}$ ) at natural food concentrations as encountered in the investigation area $\left(I_{\text {nat }}\right)$ and maximum ingestion rates $\left(I_{\max }\right)$ are given. For each of these, daily carbon uptake $\left(I_{\%}\right)$ in $\%$ of female carbon content per day at the respective food concentrations $c\left(\mu \mathrm{g} \mathrm{chl} \mathrm{a} \mathrm{l}^{-1}\right)$ is shown

\begin{tabular}{|lcccccccc|}
\hline & & & $I_{\text {nat }}$ & & & & $I_{\text {max }}$ & \\
& $I_{\text {nat }}$ & $I_{\%}$ & $C$ & & $I_{\max }$ & $I_{\%}$ & $c$ \\
\hline P. pseudodenticulata & $\leq 0.39$ & $\leq 25$ & $\leq 3.7$ & 1.33 & 84 & 6.9 \\
Ice algae & $\leq 0.40$ & $\leq 26$ & $\leq 4.8$ & & & \\
P. cf. pouchetii & $\leq 0.28$ & $\leq 18$ & $\leq 3.3$ & 1.29 & 84 & 12.4 \\
Phaeocystis bloom & $\leq 0.54$ & $\leq 35$ & $\leq 2.8$ & 4.66 & 301 & 18.5 \\
& & & & & & & \\
\hline
\end{tabular}




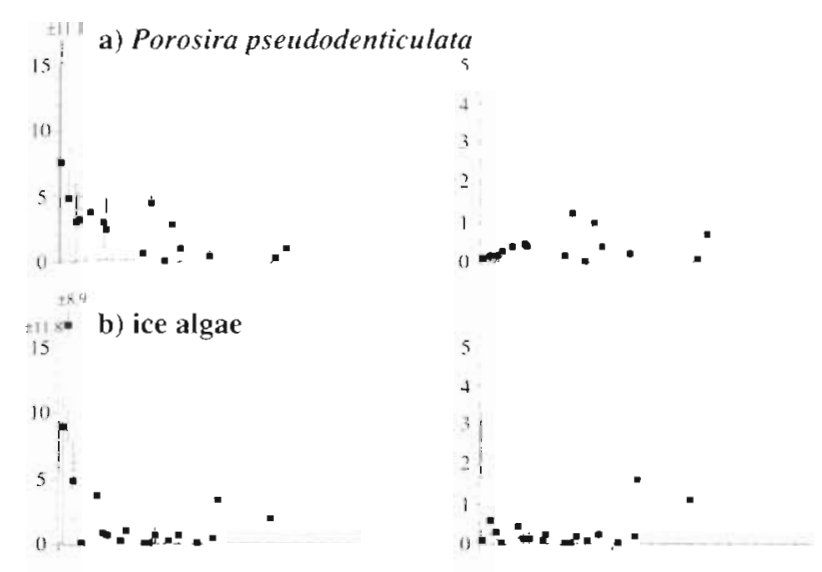

c) Phaeocystis cf. pouchetii

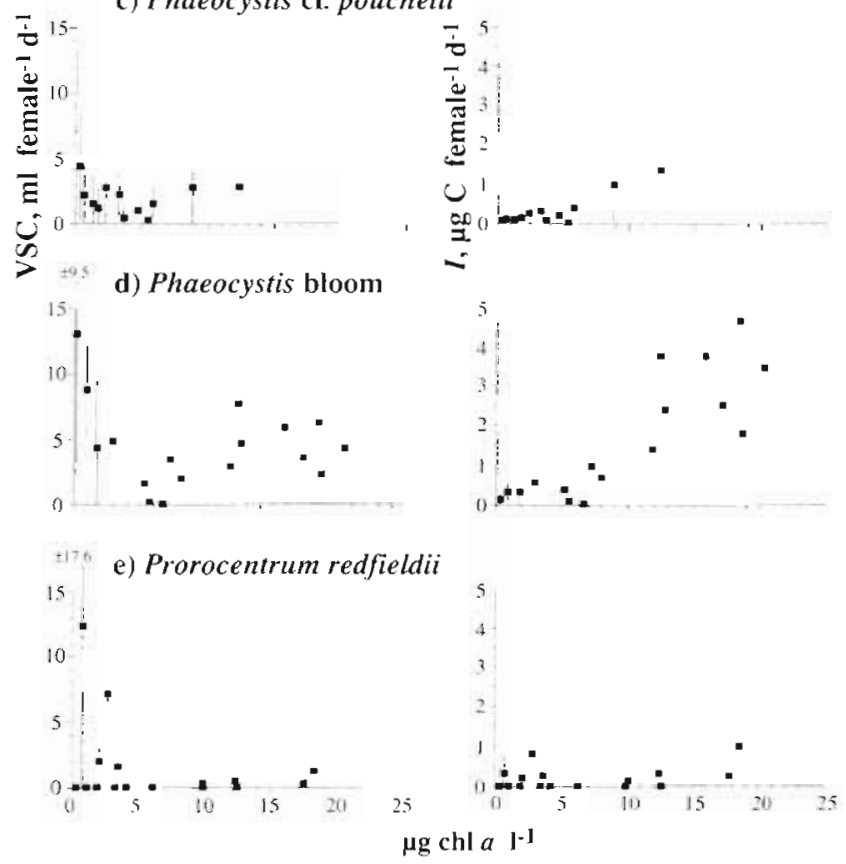

Fig. 2. Oncaea curvata. Clearance rates (volume swept clear, VSC) and ingestion rates (I) in relation to the concentration of algae in the experiments ( $\mu \mathrm{g} \mathrm{chl} \mathrm{al}^{-1}$ ). Shown are mean salues over $\left(0.5 \mu \mathrm{g} \mathrm{chl} \mathrm{a}{ }^{-1}\right)$-classes \pm mean absolute deviation from the mean (MA)

that the food conditions were not comparable with the other experiments of this series. Aggregates of algae were found instead of single cells. The resulting I values of 1.58 and $1.08 \mu \mathrm{g} \mathrm{C}$ female $\mathrm{e}^{-1} \mathrm{~d}^{-1}$ equaled 102 and $70 \%$ of body carbon and were also clearly higher than the other results of experiments with 'ice algae' (Fig. 2b). Most ingestion rates at food concentrations between 0.5 and $3.0 \mu \mathrm{g}$ chl a $\mathrm{l}^{-1}$ were between 0.2 and $0.4 \mathrm{~kg} \mathrm{C}$ female $\mathrm{d}^{-1} \mathrm{~d}^{-1}$ (13 to $26 \%$ of body carbon). At lower food concentrations the copepods generally took up less than $3 \%$ of their body carbon per day.

With the colony-forming Phaeocystis cf. pouchetii as food, only a slight decrease in VSC was found with increasing concentration (Fig. 2c). The highest measured VSC was only $16.3 \mathrm{ml}$ female $\mathrm{e}^{-1} \mathrm{~d}^{-1}$ at $0.4 \mu \mathrm{g}$ chl a

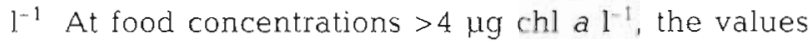
increased again. I increased with increasing food concentration (Fig. 2c) up to the highest investigated concentration of $12.4 \mathrm{\mu g}$ chl a $1^{-1}$ (see also Table 2). At chlorophyll a concentrations as encountered in the investigation area, however, I was lower (Fig. 2c, Table 2).

The culture of Phaeocystis bloom consisted mainly of flagellates, mostly Phaeocystis sp. in the colony-forming state, and the rest mainly of large planktonic diatoms. On the surface of the gelatinous Phaeocystis colonies, diatoms and other flagellates, which were either trapped or had colonized the surface, were often found. Oncaea curvata females fed with this culture showed a minimum VSC at a food concentration of $6.6 \mu \mathrm{g} \mathrm{chl} \mathrm{a} \mathrm{I}^{-1}$ (Fig. 2d). The highest measured VSC

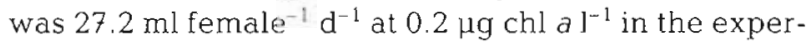
iment, and the maximum VSC at high food concentrations was $7.7 \mathrm{ml}$ female ${ }^{-1} \mathrm{~d}^{-1}$ (at $12.7 \mu \mathrm{g}$ chl a ${ }^{-1}$ ). The $I$ of $O$. curvata females increased with increasing food concentrations (Fig. 2d, Table 2). At the much lower chl a concentrations in the investigation area, I was considerably lower (Fig. 2d, Table 2).

Experiments with the flagellate Prorocentrum redfieldii showed that Oncaea curvata used this species only occasionally: $68 \%$ of all experiments of this series resulted in zero VSC and $I_{i}$ non-zero data scattered strongly. However, even with this food a decrease of VSC with increasing food concentrations is noticeable (Fig. 2e). I showed no apparent trend (Fig. 2e).

\section{Carnivorous feeding}

Carnivorous feeding of Oncaea curvata was not observed in the experiments. The copepodite stages of the 4 tested calanoids with different feeding and swimming behaviour, which were offered as food, were all recovered after each experiment. Nauplii of calanoids were also not eaten by $O$. curvata. Slight decreases of 1 and $4 \%$ of the nauplii in 2 experiments are probably due to the handling of the specimens.

\section{DISCUSSION}

There is varied and partly contradictory information about feeding of Oncaeidae in the literature, and very little information concerning Antarctic species. It seems that the species of Oncaeidae differ in their preferred food and their feeding mode. Most of the investigated species, however, were able to use gelatinous food sources or soft-bodied animals as food, and proba- 
bly prefer this type of food; the existence of such a preference is supported by the results of this study. Wickstead (1962) discussed the feeding habits of Oncaeidae and, based on their mouth parts and on behaviour studies with chaetognaths and other copepods, concluded that Oncaeidae live semi-parasitically and either graze particles from the surface of their host or penetrate the host body surface and feed on their body liquids. Kosikhina (1980) confirmed that Oncaea mediterranea and $O$. venusta preferentially eat chaetognaths (Sagitta sp.) and with this diet ingest 100 to $350 \%$ of their body weight daily. As Oncaeidae are important food organisms of chaetognaths (Hopkins 1985, Oresland 1990), predation on chaetognaths must involve a high risk for the Oncaeidae. It is therefore more likely that these Oncaeidae eat weakened or dead chaetognaths. O. mediterranea are also found in discarded houses of Larvaceae (Alldredge 1972, Ohtsuka et al. 1996), where they feed on the enriched plankton in the filters. This behaviour enables the species to feed on nanoplankton that they cannot otherwise use (Lampitt et al. 1993) and is equivalent to grazing on surfaces as described by Wickstead (1962).

Oncaea curvata females display this feeding mode in a preference for aggregates of algae or gelatinous Phaeocystis colonies as food, as the results of this study show. The highest ingestion rate from experiments with the Phaeocystis bloom was about $300 \%$ of body carbon per day. The large aggregates of the colonies are probably grazed, as was observed for appendicularian houses (Alldredge 1972). Possibly, aggregates from sinking algal and animal material as well as fecal pellets (González et al. 1994) are the main food of $O$. curvata females.

Lipid analyses support this assumption. Oncaea curvata stores mainly wax esters, and only short-chained fatty acids occur (C. Albers pers, comm.). The lipid composition with oleic acid strongly dominating the fatty acids is typical for detritus (Kattner et al. 1983) and detritus feeders.

This feeding strategy might offer an explanation for the comparatively high stock of this species in the East Wind Drift and especially in the shelf area of Antarctica. Eastwards - that is 'upstream' of the investigation area, in Marguerite Bay and in the area around Ronne Entrance - strongly developed Phaeocystis blooms were found in summer. They reached concentrations up to $5.8 \mu \mathrm{g} \mathrm{chl} \mathrm{a} \mathrm{l}^{-1}$ (Stambler 1996), which was the highest chlorophyll concentration measured during the expedition. Phaeocystis blooms like this are typical for the summer situation in this area and might provide good food conditions for the Oncaea curvata population, which could be transported by the East Wind Drift to the area around Peter I. Island within 3 mo. As Phaeocystis sp. also grows under low light conditions, live cells are found down to $100 \mathrm{~m}$ (Wassmann et al. 1990), where mainly juvenile $O$. curvata occur (Metz 1996). If juveniles also use the gelatinous Phaeocystis colonies, these blooms might help the copepods to develop rapidly. Although Phaeocystis colonies do not form aggregates (Riebesell 1993, Riebesell et al. 1995), fast sedimentation of these colonies was reported from the Barents Sea and the North Sea (Wassmann et al. 1990, Riebesell 1993). They degraded rapidly below the euphotic zone (Wassmann et al. 1990). Among other causes, feeding of zooplankton was mentioned. This study shows that $O$. curvata females, which occur mainly below the euphotic zone (>150 $\mathrm{m}$ ) in very low phytoplankton concentrations, may profit from the dying and sinking Phaeocystis colonies, especially if they are already colonized by bacteria and diatoms (Wassmann et al. 1990).

Some Oncaeidae are obviously also capable of using other phytoplankton as food. Paffenhöfer (1993) found feeding rates of 33 to $114 \%$ of body carbon per day for Oncaea mediterranea with a diet of flagellates (Rhodomonas $\mathrm{sp}$. as food for nauplii and young copepodites, and large Gymnodinium sp. as food for older copepodites and adults). A diet of diatcms, however, resulted in an increased mortality among the copepods. An investigation of gut contents of the Antarctic species $O$. curvata and $O$. antarctica (Hopkins 1985, 1987), in contrast, showed that feedirg on diatoms occurred in nature, and in the experiments of this study $O$. curvata seemed to thrive on a purely herbivorous diet. $O$. antarctica guts also contained metazooplankton, which amounted to 20 to $40 \%$ of their diet (Hopkins 1987). This concurs with observations of S. B. Schiel \& E. Mizdalski (pers. comm.) that Oncaea sp. (probably $O$. antarctica) attacked the larger calanoid copepod Metridia gerlachei and cut their abdomen or antennae off. Ohtsuka et al. (1996) also found that large Oncaeidae prey on zooplankton.

According to my investigations Oncaea curvata, unlike $O$. antarctica, feeds neither carnivorously nor semi-parasitically. All types of mobile food, such as animals or flagellates, are rejected by this species. In comparison with other Oncaeidae, $O$. curvata is a very slow, lethargic species which swims only seldom and only short distances. During the sorting of live animals from the catches, no attacks by $O$. curvata on other organisms were observed. However, O. curvata was twice found feeding on dead chaetognaths. Instead of feeding on copepods, as observed for other Oncaeidae (S. B. Schnack-Schiel \& E. Mizdalski pers. comm.), $O$. curvata was preyed upon by the omnivorous calanoids Metridia gerlachei and Calanus propinquus, but not by the herbivorous Calanoides acutus and Rhincalanus gigas (Metz \& Schnack-Schiel 1995).

Oncaea curvata can feed on diatoms, which supports the gut content analysis of Hopkins $(1985,1987)$. Feed- 
ing on the strongly pulsed diatom blooms of the Southern Ocean might be advantageous for the Oncaeidae of that area. During these short periods lipids might be stored as energy reserves for times of food shortage or reproduction. For bloom situations, as occurred in the southern Bellingshausen Sea, daily ingestion rates of 18 to $35 \%$ of body carbon can be assumed for $O$. curvata, according to this study. Thus, $O$. curvata has a higher food turnover than the large calanoids. For Metridia gerlachei, for example, daily ingestion rates of 2.1 to $7.2 \%$ of body carbon were found (Lopez \& Huntley 1995), for Calanoides acutus 5.6 to $27.0 \%$ and for Rhincalanus gigas 1.5 to $2.0 \%$ (Atkinson et al. 1992). Atkinson (1994) shows a relationship between the ingestion rate and the body mass of Antarctic copepods. Accordingly, the large calanoids have ingestion rates of $<10 \%$ of body carbon per day and small copepods up to $120 \%$. Females of $O$. curvata, with a dry weight of about $4 \mu \mathrm{g}$, would be expected to have ingestion rates of about $38 \%$ of body carbon per day, which concurs with the results of this study. According to Atkinson's (1994) relationship, juveniles should have higher ingestion rates. Several of $O$. curvata's copepodite stages occur in the euphotic zone (Metz 1996) and the biomass of the population is as high or even higher than the population biomass of some dominant calanoids, especially on the Antarctic shelf. Therefore, the influence of $O$. curvata on the phytoplankton community should prove to be as important as the influence of calanoid species.

Acknowledgements. I would like to thank Dr S. B. Schiel, Prof. G. Hempel, Prof. G.-A. Pcifenhöfer and D. Craven for valuable comments on the manuscript. The support of the captain and crew of RV 'Polarstern' is greatly appreciated. The study was financed by the Deutsche Forschungsgemeinschaft, grant Schi 329/3-1, and the Alfred-Wegener-Institut für Polar- und Meeresforschung. A stipend of the Stifterverband fur die Deutsche Wissenschaft supported the training on the methods. This is contribution no. 1270 from the AlfredWegener-Institut für Polar- und Meeresforschung.

\section{LITERATURE CITED}

Alldredge A (1972) Abandoned larvacean houses: a unique food source in the pelagic environment. Science 177 : $885-887$

Atkinson A (1994) Diets and feeding selectivity among the epipelagic copepod community near South Georgia in summer. Polar Biol 14:551-560

Atkinson. A, Ward P, Williams R, Poulet SA (1992) Feeding rates and diel vertical migration of copepods near South Georgia: comparison of shelf and oceanic sites. Mar Biol 114:49-56

Böttger-Schnack R (1990) Community structure and vertical distribution of cyclopoid copepods in the Red Sea. I. Central. Red Sea, autumn 1980. Mar Biol 106:473-485

Evans CA, O'Reilly JE (1983) A handbook for the measurement of chlorophyll a in netplankton and nannoplankton.
In: SCAR/SCOR/IABO/ACMRR Group of Specialists on Living Resources of the Southem Ocean (eds) SCAR/BIOMASS handbook, Vol 9. National Oceanic and Atmospheric Adminustration-National Marine Fisheries Center, New Jersey, p 1-44

Frost BW (1972) Effects of size and concentration of food particles on the feeding behavior of the marine planktonic copepod Calanus pacificus. Limnol Oceanogr 17:805-81.5

González HE, Kurbjeweit F. Bathmann UV (1994) Occurrence of cyclopoid copepods and faecal material in the Halley Bay region, Antarctica, during January-February 1991. Polar Biol 14.331-342

Hopkins TL (1985) Food web of an Antarctic midwater ecosystem. Mar Biol 89:197-212

Hopkins TL (1987) Midwater food web in McMurdo Sound, Ross Sea, Antarctica. Mar Biol 96:93-106

Hopkins TL, Torres JJ (1988) The zooplankton community in the vicinity of the ice edge, western Weddell Sea, March 1986. Polar Biol 9:79-87

Kattner G, Gerken G, Eberlein K (1983) Development of Jipids during a spring plankton bloom in the northern North Sea. 1. Particulate fatty acids. Mar Chem 14:149-162

Kellermann A (1987) Food and feeding ecology of postlarval and juvenile Pleuragramma antarcticum (Pisces; Notothenioidei) in the seasonal pack ice zone off the Antarctic Peninsula. Polar Biol 7:307-315

Kosikhina oV (1980) Feeding of marine copepods of the genus Oncaea (Cyclopoida). Ekol Morja 4:46-49 (in Russian)

Lampitt RS, Wishner KF, Turley CM, Angel MV (1993) Marine snow studies in the Northeast Atlantic Ocean: distribution, composition and role as a food source for migrating plankton. Mar Biol 116:689-702

Lenz J (1974) Untersuchung zum Nahrungsgefüge im Pelagial der Kueler Bucht. Der Gehalt an Phytoplankton, Zooplankton und organischem Detritus in Abhängigkeit von Wasserschichtung, Tiefe und Jahreszeit. Habilitationsschrift, Universität Kiel

Lopez MDG, Huntley ME (1995) Feeding and diel vertical migration cycles of Metridia gerlachei (Giesbrecht) in coastal waters of the Antarctic Peninsula. Polar Biol 15: 21-30

Metz C (1996) Lebensstrategien dominanter antarktischer Oithonidae (Cyclopoida, Copepoda) und Oncaeidae (Poecilostomatoida, Copepoda) im Bellingshausenmeer. Ber Polarforsch 207:1-123 (PhD thesis, English abstract)

Metz C. Schnack-Schiel SB (1995) Observations on carnivorous feeding in Antarctic calanoid copepods. Mar Ecol Prog Ser 129:71-75

Nishida $S$ (1985) Taxonomy and distribution of the family Oithonidae (Copepoda, Cyclopoida) in the Pacific and Indian Oceans. Bull Ocean Res Inst Univ Tokyo 20

Ohtsuka S, Böttger-Schnack R, Okada M, Onbé T (1996) In situ feeding habits of Oncaea (Copepoda: Poecilostomatoida) from the upper $250 \mathrm{~m}$ of the central Red Sea, with special reference to consumption of appendicularian houses. Bull Plankton Soc Jpn 43:89-105

Øresland V (1990) Feeding and predation impact of the chaetognath Eukrohnia hamata in Gerlache Strait, Antarctic Peninsula. Mar Ecol Prog Ser 63:201-209

Øresland V, Ward P (1993) Summer and winter diet of four carnivorous copepod species around South Georgia. Mar Ecol Prog Ser 98:73-78

Paffenhofer GA (1993) On the ecology of marine cyclopoid copepods (Crustacea, Copepoda). J Plankton Res 15 $37-55$

Riebesell U (1993) Aggregation of Phaeocystis during phyto- 
plankton spring blooms in the southern North Sea. Mar Ecol Prog Ser 96:281-289

Riebesell U, Reigstad M, Wassmann P, Noji T, Passow U (1995) On the trophic fate of Phaeocystis pouchetii (Hariot): VI. Significance of Phaeocystis-derived mucus for vertical flux. Neth J Sea Res 33:193-203

Schnack S, Marschall S, Mizdalski E (1985) On the distribution of copepods and larvae of Euphausia superba in Antarctic waters during February 1982. Meeresforschung 30:251-263

Stambler N, Reynolds R, Bracher A, Hoge U, Tilzer M (1996) Biooptik. Ber Polarforsch 188:58-64

Editonal responsibility: Otto Kinne (Editor), Oldendorf/Luhe, Germany
Turner JT (1986) Zooplankton feeding ecology: contents of fecal pellets of the cyclopoid copepods Oncaea venusta, Corycaeus amazonicus, Oithona plumifera, and $O$. simplex from the northern Gulf of Mexico. PSZN I: Mar Ecol 7:289-302

Turner JT, Dagg MJ (1983) Vertical distributions of continental shelf zooplankton in stratified and isothermal waters. Biol Oceanogr 3:1-40

Wassmann P, Vernet M, Mitchell BG, Rey F (1990) Mass sedimentation of Phaeocystis pouchetii in the Barents Sea. Mar Ecol Prog Ser 66:183-195

Wickstead JH (1962) Food and feeding in pelagic copepods. Proc Zool Soc Lond 139:545-555

Submitted: June 13, 1997; Accepted: March 5, 1998 Proofs received from author(s): July 7, 1998 